\title{
Teknologi Elektronis Pengkajian Nyeri Kronis pada Anak-anak dan Remaja
}

\author{
Dwi Novrianda ${ }^{a}$ \\ aprogram Studi Ilmu Keperawatan Universitas Andalas \\ Email: dwinov_82@yahoo.co.id
}

\begin{abstract}
Chronic pain in children and adolescents is a problem that can affect every aspect of individual functions. The big change in the quality of life of a child dealing with chronic pain. Impaired function generally occurs ie sleeping, employment, social functioning and daily activities. Monitoring of chronic pain should be a concern to the clinician in monitoring the way the pain so as to provide effective care and treatment. Pain is a subjective thing and needs expressed by individuals who experience such pain. One method of assessment of chronic pain in children and adolescents that can be applied in clinical practice is the use of electronic pain diary that combines handheld hardware technology advances such as smart phones and PDAs with pain assessment software program innovations that have proven their quality index. In order to use this application to apply the necessary attention to the ethical aspects, financial aspects of the tools and training, aspects of change in perspective on the importance of understanding the chronic pain patient in order to change behavior.
\end{abstract}

Keywords :Chronic pain, pain assessment, electronic pain diary, technology

\begin{abstract}
Abstrak : Nyeri kronis pada anak-anak dan remaja merupakan permasalahan yang dapat mempengaruhi setiap aspek fungsi individu. Perubahan besar dalam kualitas hidup seorang anak berhubungan dengan nyeri kronis. Gangguan fungsi yang umumnya terjadi yaitu tidur, ketenagakerjaan, fungsi sosial dan kegiatan sehari-hari. Monitor terhadap nyeri kronis perlu menjadi perhatian bagi klinisi dalam memantau perjalanan nyeri sehingga dapat memberikan perawatan dan pengobatan yang efektif. Nyeri merupakan hal yang subjektif dan perlu diutarakan oleh individu yang mengalami nyeri tersebut. Salah satu metode pengkajian nyeri kronis pada anak-anak dan remaja yang dapat diaplikasikan pada praktik klinis adalah penggunaan electronic pain diary yang menggabungkan kemajuan teknologi handheld hardware seperti ponsel pintar dan PDA dengan inovasi program software pengkajian nyeri yang telah terbukti indeks kualitasnya. Agar penggunaan aplikasi ini dapat diterapkan maka diperlukan perhatian pada aspek etika, aspek pendanaan perangkat dan pelatihan, aspek perubahan cara pandang tentang pentingnya memahami nyeri kronis pasien dalam rangka perubahan perilaku.
\end{abstract}

Kata kunci: nyeri kronis, pengkajian nyeri, electronic pain diary, teknologi

Kebanyakan penyakit yang dialami manusia memiliki gejala nyeri. Nyeri yang dirasakan akan berbeda-beda pada setiap individu, baik tingkat nyeri, intensitas, lokasi, gambaran rasa nyeri, durasi, maupun cara penanganan nyeri tersebut. Untuk mengetahui kualitas dan kuantitas nyeri tersebut diperlukan informasi dari penderita nyeri tersebut sehingga dapat menentukan penanganan nyeri yang tepat. 
Pengkajian dan manajemen nyeri yang adekuat merupakan komponen kritis dari asuhan keperawatan pada anak-anak dari seluruh kelompok usia di rumah sakit anak-anak (Ellis et al, 2007, Marceau et al, 2011). Kontrol nyeri yang tidak adekuat dihubungkan dengan kriteria pasien negatif seperti ketidakpatuhan pada regimen pengobatan, inaktivitas dan tirah baring memanjang (Puntillo dan Weiss, 1994 dalam Ellis et al, 2007), masa rawat yang lama (Jackson, 1989) dan perkembangan menjadi nyeri kronis (Johnston, Abott, Gray-Donald \& Jeans, 1992, Macrae, 2001).

Anak-anak dan remaja juga dapat mengalami nyeri sebagai akibat dari penyakit yang mereka derita. Salah satu jenis nyeri yang dialami oleh anak-anak dan remaja adalah nyeri kronis. Beberapa penyakit yang diderita oleh anak-anak yang memiliki gejala nyeri kronis seperti juvenile idiopathic arthritis, anemia sel sabit, kanker, spina bifida, hemofilia, dan lainlain.

Nyeri kronis dan nyeri terkait ketidakmampuan merupakan masalah kesehatan yang signifikan pada anak-anak dan remaja. Nyeri kronis secara signifikan merusak kualitas hidup anak-anak, menyebabkan ketidakmampuan fisik dan distress emosional. Meskipun perkiraan yang tepat dari prevalensi nyeri kronis sulit dipastikan, sekitar $15 \%$ - $25 \%$ dari anakanak diduga mengalami nyeri kronis dan berulang. Kompleksitas dari nyeri kronis membutuhkan pengkajian yang reliable dan valid terhadap berbagai dimensi nyeri untuk mengevaluasi penatalaksanaan nyeri secara komprehensif. Langkah-langkah yang ada masih mengandalkan ingatan sehingga tidak memungkinkan untuk penilaian prospektif longitudinal di lingkungan naturalistik seperti rumah dan sekolah dan pada akhirnya menemui kegagalan untuk menggabungkan sifat multidimensional nyeri (Stinson, 2009, Stinson et al, 2011).

Pendekatan Real-time data capture (RTDC) menggunakan diary electronic telah diajukan sebagai standar baru untuk mengukur nyeri. Pendekatan RTDC, dimana pasien melaporkan bagaimana perasaan saat itu dengan menggunakan buku harian/diary nyeri dapat meminimalkan masalah recall bias dengan memungkinkan pengumpulan data real time sesaat dari pasien dan meningkatkan validitas ekologi (merefleksikan kenyataan hidup setiap harinya). Paper diary biasanya digunakan pada praktik klinis dan riset. Namun, paper diary mengalami beberapa keterbatasan yang penting, meliputi ketidakpatuhan pasien dan ketidakakuratan dalam memasukkan data. Pada orang dewasa, electronic pain diary (seperti personal digital assistant [PDA]) telah digunakan sebagai cara yang efektif untuk memaksimalkan kepatuhan pasien dengan menyelesaikan peringkat intensitas nyeri kronis dan validitas peringkat nyeri mereka. Kepatuhan ditingkatkan oleh fitur sinyal dari buku harian elektronis, dimana pasien diingatkan oleh bunyi atau sinyal dari perangkat kapan waktu untuk menyelesaikan catatan harian. Oleh karena itu, electronic pain diary yang menggunakan RTDC diajukan sebagai standar baru untuk mengukur nyeri kronis karena mereka menyingkirkan permasalahan tersebut (Stinson, 2009).

Walaupun electronic diary sudah lazim, penggunaannya sangat sedikit pada anak-anak. Electronic diary harus dipelajari lebih komprehensif pada anak-anak dengan memberikan pertimbangan khusus terhadap masalah perkembangan (seperti usia dan tahap perkembangan) yang dapat mempengaruhi validitas hasil, dan kegunaan serta kelayakan (kepatuhan dan penerimaan) dari metode ini pada populasi anak-anak (Stinson, 2009). Menurut Malviya (2006) pengkajian nyeri yang komprehensif seharusnya meliputi tujuan berikut ini 1) mendeteksi kehadiran nyeri, 2) mengukur beratnya nyeri, 3) memperkirakan dampak potensial nyeri pada individu, 4) menentukan pengukuran yang sebaiknya digunakan untuk menurunkan nyeri, dan 5) 
mengevaluasi efektivitas dan efek samping dari pengukuran.

Tujuan dari artikel ini adalah untuk mengkaji literatur electronic pain diary untuk anak-anak dan mendiskusikan metode penggunaan electronic pain diary untuk melaksanakan pengkajian nyeri kronis pada anak-anak.

\section{PEMBAHASAN}

Definisi nyeri menurut batasan yang digunakan oleh International Association for the Study of Pain (IASP) adalah "an unpleasant sensory and emotional experience associated with actual or potential tissue damage, or described in terms of such damage" (Fishman et al, 2009).

Nyeri terjadi apabila terdapat rangsangan mekanikal, termal atau kimiawi yang melewati ambang rangsang tertentu. Rangsangan ini terdeteksi oleh nosiseptor yang merupakan ujung-ujung saraf bebas. Rangsangan akan dibawa sebagai impuls saraf melalui serabut A delta yang bermielin, berkecepatan hantar yang cepat dan bertanggung jawab terhadap nyeri yang cepat, tajam, terlokalisasi serta serabut $\mathrm{C}$ yang tidak bermielin berkecepatan hantar saraf lambat dan bertanggung jawab atas nyeri yang tumpul dan tidak terlokalisasi dengan jelas (Simpson et al, 2012).

Berdasarkan mekanisme terjadinya, menurut Simpson et al (2012) nyeri terbagi menjadi nyeri nosiseptif dan nyeri neuropatik. Nyeri nosiseptif disebabkan adanya kerusakan jaringan yang mengakibatkan dilepaskannya bahan kimiawi yang disebut excitatory neurotransmitter seperti histamin dan bradikinin, yang bertanggung jawab terhadap timbulnya reaksi inflamasi. Selanjutnya bradikinin melepaskan prostaglandin dan substansi $\mathrm{P}$ yang merupakan neurotransmitter kuat.

Nyeri nosiseptif dibagi menjadi nyeri viseral dan nyeri somatik. Nyeri viseral terjadi akibat stimulasi nosiseptor yang berada di rongga abdominal dan rongga thoraks. Nyeri somatik terbagi menjadi nyeri somatik dalam dan nyeri kutaneus. Nyeri somatik dalam berasal dari tulang, tendon, saraf dan pembuluh darah, sedangkan nyeri kutaneus berasal dari kulit dan jaringan bawah kulit (HockenberryEaton et al, 1999).

Nyeri neuropatik berasal dari kerusakan jaringan saraf akibat penyakit atau trauma. Nyeri neuropatik perifer apabila disebabkan oleh lesi saraf tepi, dan nyeri sentral apabila disebabkan lesi pada otak, batang otak atau medula spinalis (Hockenberry-Eaton et al, 1999).

Nyeri akut merupakan nyeri yang terjadi dalam waktu cepat, penyebabnya jelas seperti jejas atau lesi jaringan lunak, infeksi atau inflamasi. Pada umumnya nyeri akut bersifat temporer, berlangsung kurang dari 6 bulan (3-6 bulan), dapat berhenti tanpa terapi atau berkurang sejalan dengan penyembuhan jaringan atau apabila penyebab nyeri dihilangkan atau memberi respons baik terhadap penatalaksanaan sederhana seperti istirahat dan analgetik atau pengobatan kausal lain. Kegagalan terapi nyeri akut dapat menimbulkan nyeri kronis (Fishman et al, 2009).

Nyeri kronis adalah nyeri yang berlarut-larut, memanjang, lama sesudah lesi atau penyakit awal yang menimbulkan nyeri tersebut sembuh. Pada nyeri kronis seringkali tidak ditemukan penyebab nyeri yang jelas atau dapat diidentifikasi. Nyeri kronis dapat berlangsung berbulan-bulan dan seakan-akan tidak dapat disembuhkan, sehingga dapat disebut sebagai penyakit tersendiri (pain illness) (Fishman et al, 2009).

Ketidakjelasan nyeri kronis seringkali menimbulkan berbagai gangguan psikologis seperti depresi, kelelahan yang berlebihan, insomnia, anoreksia, apati dan perilaku sakit. Apabila nyeri kronis ini sangat berat, sama seperti pada stress yang kronis, akan mengaktifasi sistim saraf parasimpatis, dan mengakibatkan tegangan otot yang berlebihan, mengganggu tekanan darah dan denyut nadi dan menurunnya sistem pertahanan tubuh. 
Penatalaksanaan nyeri kronis seringkali memerlukan penanganan multidispliner dari berbagai bidang spesialisasi, serta penanganan intradisipliner berbagai profesi dalam tim rehabilitasi medik (Stannard et al, 2011). Sebelum merencanakan program rehabilitasi yang komprehensif untuk menangani nyeri, digunakan berbagai alat ukur untuk mengkuantifikasi nyeri dan mendapatkan berbagai keterangan tambahan yang akan menentukan program penatalaksanaan nyeri kronis. Salah satu alat ukur yang saat ini dikembangkan dalam mengkaji kuantitas dan kualitas nyeri kronis adalah electronic diary yang mengintegrasikan antara teknologi hardware dengan program software pengkajian nyeri yang telah diuji kualitasnya.

Terdapat tiga pilihan teknologi yang dapat digunakan untuk mengkaji nyeri secara elektronis yaitu pain mapping, integrasi software program nyeri, dan electronic monitoring hardware. Pain mapping dengan diagram 2D telah digunakan untuk mendiagnosa masalah nyeri pasien dengan cara meminta pasien melaporkan nyerinya secara verbal dan menandai lokasi nyeri pada diagram yang memperlihatkan gambaran tubuh manusia. Namun, metode 2D ini tidak memungkinkan pasien untuk menilai tingkat intensitas nyeri dan kedalaman nyeri. Kemudian dikembangkan model 3D sehingga dapat mengetahui distribusi dan intensitas nyeri. Melalui rotasi model tubuh dapat menampilkan berbagai gambaran dimana pasien dapat menunjukkan lokasi nyeri lebih akurat, intensitas nyeri, dan bahkan kedalaman nyeri dengan menandai titik di dalam model (Gambar 1) (Marceau et al, 2011).

Program pengkajian nyeri elektronis yang komprehensif berpotensi untuk mendorong pasien dan dokter dalam memodifikasi perawatan, membantu pasien memahami gejalanya dan manajemen gejala. Program ini memungkinkan staf klinis untuk mengkaji laporan diri nyeri pasien beserta dampak psikologis dan emosional pada pasien. Pasien dapat mengirimkan data sesegera mungkin melalui akses internet dan para klinisi dapat mengakses data tersebut dimanapun. Program ini juga memiliki kemampuan untuk diintegrasikan dengan catatan medis elektronis. Review ringkasan data pasien secara instan oleh dokter merupakan kunjungan ulang yang berpotensi untuk mengetahui perubahan terhadap sakit, mood, gangguan aktivitas dan manfaat pengobatan. Program ini memiliki pilihan untuk mensintesis data ke dalam dokumen ringkasan dilengkapi rekomendasi pengobatan bagi pasien dan penyedia. Selanjutnya program ini juga menyediakan ringkasan elektronis atau cetakan data nyeri, saran pengobatan bagi penyedia untuk masing-masing diagnosa serta informasi kejiwaan, riwayat penyalahgunaan substansi/zat dan kondisi medis penyerta (Marceau et al, 2011).

Banyak program yang tersedia dan sedang dalam pengembangan untuk mengkaji nyeri dan kualitas hidup pasien dengan nyeri kronis. Saat ini terdapat sejumlah sistem komputer dan program software yang sedang dikembangkan untuk mengkaji dan mengelola nyeri secara komprehensif. Selain itu juga terdapat informasi berbasis web dan situs pengkajian nyeri bagi pasien dan klinisi seperti Aana.com, Achenet.org, Ampainsoc.org, Asahq.org, Aapainmanage.org, Healt.com, IASP-pain.org, Pain ACTION.org, Pain EDU.org, Painmed.org, Rsds.ORG, Spinehealth.com,

Spineuniverse.com, Theacpa.org. Website ini telah dievaluasi oleh dokter yang terdiri dari 16 item kriteria dalam 5 domain yaitu etiologi, diagnosis, tujuan pengobatan, pilihan pengobatan, dan penyalahgunaan substansi/zat. Sebanyak 240 website dievaluasi dan skor rata-rata dari Quality Website Index (QWI, berkisar dari $-16=$ terendah hingga $+16=$ terbaik) adalah 2.17 ( $\mathrm{SD}=3.3$ ). Marceau et al. (2011) menyimpulkan bahwa kualitas keseluruhan website bervariasi dan berkisar 
dari terendah hingga terbaik. Lokasi website pada tiga search engine utama secara signifikan memiliki skor lebih tinggi dibandingkan yang bukan search engine utama. Marceau et al. (2011) merekomendasikan agar klinisi menyarankan website nyeri kronis dengan

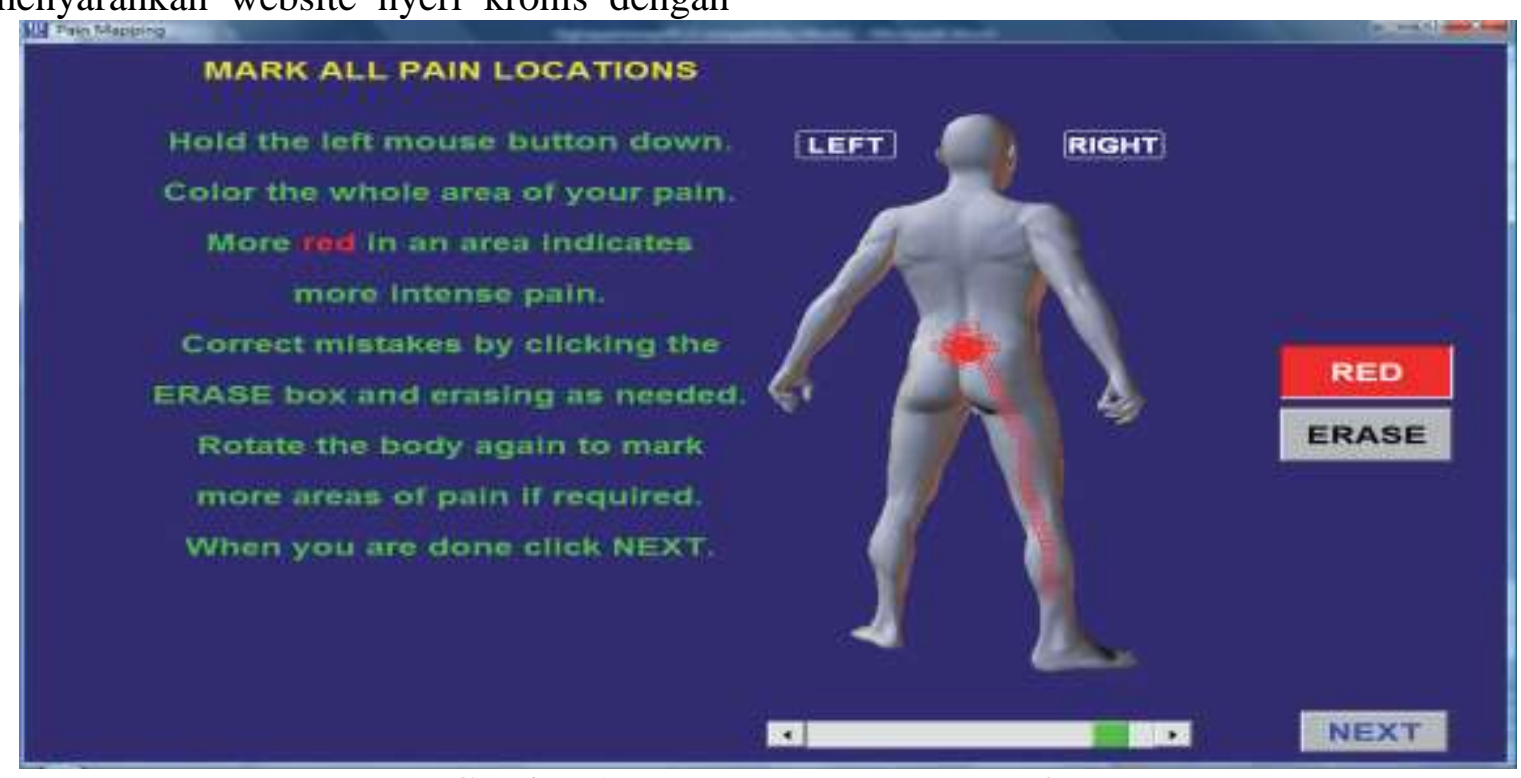

Gambar 1. Program Pain Mapping 3D

Sumber: Jamison, et al (2011) dalam Marceau et al (2011) indeks kualitas tinggi bagi pasien sehingga informasi lebih akurat dapat dilihat pada gambar 1.
Semenjak munculnya komputer personal, telah terjadi perubahan yang fantastis dalam rancangan teknologi pengkajian nyeri. Saat ini perangkat handheld seperti PDA dan ponsel dapat menyimpan banyak informasi dibandingkan perangkat sebelumnya dimana diperkirakan dalam beberapa tahun mendatang ponsel mampu menyimpan data terabyte (lebih dari satu triliun byte atau 1024 GB). Chip komputer membuat perangkat bekerja lebih cepat dan mengurangi biaya karena harga memori yang tidak mahal sehingga tidak perlu kuatir dalam menghapus data atau kehilangan data. Selanjutnya ukuran perangkat yang mengecil seperti ukuran saku sehingga dapat dibawa kemana-mana (portable). Kebanyakan perangkat ini juga memiliki akses internet sehingga dapat mengakses jaringan nirkabel kapan saja dan dimana saja. Selain itu juga terdapat pengumpulan data pasif seperti posisi tubuh, gerakan suhu, denyut jantung, dan respirasi dengan perekam data aktivitas yang saat ini tersedia untuk aktivitas tidur dan gerakan fisik, sehingga dapat diterapkan untuk melacak nyeri (Marceau et al, 2011).

Pada nyeri kronis dibutuhkan informasi tentang nyeri secara faktual. Oleh karena itu Marceau et al (2011) menyatakan saat ini perhatian muncul terhadap adanya keterbatasan memori manusia dalam mengingat kejadian nyeri. Pendekatan RTDC menjadi sarana penting untuk mengurangi bias dari informasi memori. Ecological momentary asssessment (EMA) merupakan salah satu metode pengambilan informasi laporan diri secara real time. Hal ini meliputi pengamatan berulang dan penggunaan electronic diary pada lingkungan pasien. Selanjutnya Stinson et al (2008) menyatakan bahwa penggunaan PDA untuk electronic pain diary dengan metode RTDC telah diajukan sebagai standar baru untuk mengukur nyeri karena dapat menghilangkan permasalahan 
metodologi seperti recall bias, ketidakpatuhan.

Munculnya program software pengamatan nyeri pada ponsel pintar dan PDA (misalnya Palm atau perangkat iPAQ) memungkinkan untuk pengumpulan datasets yang besar dari data sesaat. Hal ini diyakini bahwa pengumpulan peringkat intensitas nyeri beberapa kali sepanjang hari akan lebih menguntungkan dalam memahami sifat alamiah nyeri dibandingkan pengumpulan data yang jarang (seperti satu kali seminggu) (Marceau et al, 2011). Adanya integrasi antara perangkat keras (hardware) dan program software pengkajian nyeri yang real time dapat memenuhi kebutuhan klinis dalam mengumpulkan data nyeri kronis pasien secara lebih akurat dan sepanjang waktu sehingga manajemen nyeri kronis lebih efektif.

Penelitian yang dilakukan di antara pasien nyeri kronis untuk membandingkan peringkat nyeri, gangguan aktivitas dan mood di klinik secara bulanan dan di rumah secara harian dengan menggunakan electronic diary. Hipotesisnya adalah bahwa peringkat harian nyeri di rumah akan memperlihatkan informasi klinis yang lebih berguna daripada yang tersedia di klinik secara bulanan selama sesi kunjungan bulanan. Sebanyak 41 pasien nyeri kronis nonkanker diminta untuk menggunakan electronic diary segera sebelum setiap kunjungan klinik bulanan selama 10 bulan dan melengkapi program electronic diary yang sama di rumah setiap hari selama 4 minggu. Electronic diary terdiri dari 25 item set komprehensif, menggabungkan pertanyaan dari Brief Pain Inventory (beratnya nyeri, gangguan aktivitas, fungsi dan mood), pertanyaan medis, dan lokasi nyeri pada Hewlett Packard (C) iPAQ hx2410 Pocket PC. Subjek diminta untuk menilai rata-rata, terburuk, paling dan sekarang sakit dari 0 = tidak ada rasa sakit sampai $10=$ nyeri terburuk. Keempat peringkat ditambahkan dan dan untuk mendapatkan gabungan intensitas nyeri dibulatkan ke desimal kesepuluh terdekat. Setelah 10 bulan subjek diminta untuk menyelesaikan 12 item survei paska perawatan tentang manfaat dari pengumpulan data diary. Hasil menunjukkan bahwa peringkat bulanan di klinik selama 10 bulan sangat berhubungan dengan peringkat harian di rumah selama 1 bulan (rata-rata nyeri $\mathrm{r}=0.90$, rata-rata gangguan $r=0.94$, rata-rata mood $r=0.89$ ), meskipun ada perbedaan standar deviasi. Meskipun data catatan harian berkorelasi dengan data bulanan di klinik, dapat bermanfaat dalam menentukan pola nyeri jangka pendek dan keefektifan pengobatan yang tidak tersedia di klinik (Marceau et al, 2011).

Stinson, Stevens, Feldman, Streiner, McGrath, Dupuis, Gill \& Petroz (2011) pada penelitian "Using an electronic pain diary to better understand pain in children and adolescents with arthritis" memberi hasil bahwa rata-rata partisipan melaporkan tingkat nyeri ringan, keadaan yang tidak menyenangkan dan mengganggu, serta kekakuan dan tingkat kelelahan dari ringan sampai sedang. Penelitian ini dilakukan pada 76 orang anak-anak berusia $9-18$ tahun dengan juvenile idiopathic arthtritis yang direkrut dari Pusat Perawatan Tertier Anak Canada dan meminta mereka untuk mencatat nyeri yang dialami 3 kali sehari selama 2 minggu menggunakan e-Ouch pain diary. Penelitian ini mendukung penggunaan e-Ouch pain diary pada setiap aplikasi klinis untuk mengukur kriteria evaluasi pasien karena mudah dipahami tentang bagaimana nyeri yang dialami pasien dan perubahan gejala lainnya sepanjang hari pada anak dengan juvenile idiopathic arthritis serta bagaimana cara terbaik untuk merawat mereka.

Berdasarkan penelitian tersebut, diketahui bahwa catatan harian secara elektronis dapat merekam perjalanan nyeri sehingga para klinisi dapat menentukan pola nyeri dan pendekatan perawatan maupun pengobatan yang tepat. Oleh karena itu perlu dirancang metode yang tepat dalam pengkajian nyeri kronis pada anak-anak dan 
remaja dengan memperhatikan usia dan tahap tumbuh kembang. Selanjutnya menurut penelitian Stinson et al (2011) pada anak-anak dan remaja JA (juvenile arthritis) dengan menggunakan electronic pain diary untuk memahami nyeri mereka bahwa metode ini bisa dilakukan dan direkomendasikan dengan menggabungkan e-Ouch pain diary dalam aplikasi klinis setiap hari.

\section{KESIMPULAN}

Nyeri kronis pada dasarnya merupakan pengalaman subjektif yang dialami oleh pasien. Anak-anak dan remaja bisa saja mengalami nyeri kronis akibat kondisi suatu penyakit. Anak-anak dan remaja dapat dimintai informasi tentang pengalaman nyeri kronis yang mereka alami agar dapat menentukan program penatalaksaan yang tepat dan efektif. Metode electronic pain diary dapat menjadi standar dalam mengumpulkan data nyeri kronis yang dialami oleh anak-anak dan remaja melalui integrasi program software yang tepat sesuai usia dan tumbuh kembang anak dan remaja dengan teknologi hardware.

Dalam menerapkan aplikasi electronic pain diary perlu memperhatikan aspek etika, sistem informasi manajemen, biaya yang dibutuhkan dan perilaku yang diharapkan. Oleh karena itu dapat diajukan beberapa rekomendasi sebagai berikut :

1. Kepada pihak manajemen rumah sakit diharapkan dapat menerapkan sistem manajemen yang bisa memberikan perlindungan terhadap informasi dan keputusan terhadap siapa yang berwenang mengakses dan menyimpan informasi tersebut.

2. Pihak manajemen rumah sakit hendaknya memberikan perhatian terhadap anggaran pengadaan, pemeliharaan dan peningkatan hardware dan software yang dibutuhkan serta pelatihan sumberdaya manusia dalam penerapan aplikasi ini.

3. Para klinisi dan pasien diharapkan dapat mengubah perilaku mereka melalui perubahan cara pandang tentang pentingnya pemahaman rasa nyeri pada pasien sehingga dapat mengelola nyeri secara efektif.

\section{DAFTAR PUSTAKA}

Ellis, J.A., McCleary, L., Blouin, R., Dube, K., Rowley, B., MacNeil, M., Cooke, C. (2007). Implementing best practice pain management in a pediatric hospital. Journal for Specialist in Pediatric Nursing. Oct 2007, 12 (4): 264-277. ProQuest.

Fishman, S.M., Ballantyne, J.C., Rathmell, J.P. (2009). Bonica's management of pain. Fourth edition. USA: Lippincott Williams \& Wilkins.

Hockenberry-Eaton, M., Barrera, P., Brown, M., Bottomley, S.J., O’Neill, J.B. (1999). Pain management in children with cancer. The State of Texas: Texas Cancer Council.

Malviya, S. (2006). Assessment of pain in children. Presented at SPA Annual Meeting.

Marceau, L.D., Smith, L.D., Jamison, R.N. (2011). Electronic pain assessment in clinical practice. Pain Manage. 1 (4): 325-336.

Simpson, D.M., McArgnothur, J.C., Dworkin, R.H. (2012). Neuropatic pain: mechanism, diagnosis and treatment. New York: Oxford University Press.

Stannard, C., Kalso, E., Ballantyne, A. (2011). Evidence-based chronic pain management. USA: Wiley-Blackwell.

Stinson, J.N., Petroz, G.C., Stevens, B.J., Feldman, B.M., Streiner, D., McGrath, P.J., Gill, N. (2008). Working out the kinks: testing the feasibility of an electronic pain diary for adolescents with arthritis. The Journal of the Canadian Pain Society. Sep/Oct 2008, 13 (5): 375-382. Proquest Psychology Journal.

Stinson, J.N. (2009). Improving the assessment of pediatric chronic pain: harnessing the potential of electronic 
diaries. Pain research and management: The Journal of the Canadian Pain Society. Jan/Feb 2009, 14 (1): 59-64. ProQuest Psychology Journal.

Stinson, J.N., Stevens, B.J., Feldman, B.M., Streiner, D.L., McGrath, P.J., Dupuis,
A., Gill, N., Petroz, G.C. (2011). Using an electronic pain diary to better understand pain in children and adolsescents with arthritis. Pain Manage. 1 (2): 127-137. 